Article

\title{
Mn-corrolazine-based 2D-nanocatalytic material with single Mn atoms for catalytic oxidation of alkane to alcohol
}

\author{
Chun Zhu a, Jin-Xia Liang b, Yang Meng a, Jian Lin c,*, Zexing Cao d,\# \\ a School of Chemistry and Chemical Engineering, Guizhou University, Guiyang 550025, Guizhou, China \\ b Guizhou Provincial Key Laboratory of Computational Nano-Material Science, Guizhou Education University, Guiyang 550018, Guizhou, China \\ c CAS Key Laboratory of Science and Technology on Applied Catalysis, Dalian Institute of Chemical Physics, Chinese Academy of Sciences, Dalian 116023, \\ Liaoning, China \\ d State Key Laboratory of Physical Chemistry of Solid Surfaces and Fujian Provincial Key Laboratory of Theoretical and Computational Chemistry, \\ College of Chemistry and Chemical Engineering, Xiamen University, Xiamen 360015, Fujian, China
}

\section{A R T I C L E I N F O}

\section{Article history:}

Received 6 July 2020

Accepted 25 August 2020

Available online 22 November 2020

\section{Keywords:}

Single-atom catalyst

Heterogenization

Two-dimensional nanomaterials

First-principles calculations

$\mathrm{C}-\mathrm{H}$ bond activation

\begin{abstract}
A B S T R A C T
Heterogenization of organic-macrocyclic metal catalysts is one of the simplest and most efficient methods for effective separation of products and cyclic application of a catalyst. By using an environmentally friendly Mn-corrolazine catalyst as the building unit, which can directly oxidize organic substrates under oxygen atmosphere and mild conditions, we theoretically constructed a novel two-dimensional (2D) Mn-corrolazine nanocatalytic material with high catalytic activity. In this material, each $\mathrm{Mn}$ atom maintains its electronic configuration in the monomer and can directly activate $\mathrm{O}_{2}$ as the single-atom catalyst (SAC) center to form a radical-like [Mn]-0-0 under mild visible-light irradiation conditions. The newly generated [Mn]-0-0 can efficiently and selectively oxidize $\mathrm{C}-\mathrm{H}$ bonds to form alcohol species through $\mathrm{H}$-abstraction and the rebound reaction. Moreover, the catalytic reaction is easily regulated by an external electric field along its intrinsic Mn-0-0 reaction axis. The current study provides a theoretical foundation for further experimental studies and practical applications of the Mn-corrolazine-based SAC.
\end{abstract}

(C) 2021, Dalian Institute of Chemical Physics, Chinese Academy of Sciences. Published by Elsevier B.V. All rights reserved.

\section{Introduction}

Corrole [1-4], a porphyrinoid aromatic macrocyclic system constructed by four conjugated pyrrole rings, has entered a new stage after the breakthrough advances to address synthetic technology bottlenecks [5], and has attracted significant research interest owing to its superior photoelectric properties and its increasing applications in catalysis, dye-sensitized solar cells (DSSCs), sensors, and medicines. Several reviews [1,2,6-9] present recent advances in the synthesis of corrole derivatives and strategies for corrole functionalization. It is well-known that corrole has one meso-carbon atom less than porphyrins, which leads to a smaller cavity of the corrole ring $[10,11]$ in favor of stabilizing high-valent transition metals [M(III), M(IV), $\mathrm{M}(\mathrm{V})$, or $\mathrm{M}(\mathrm{VI}) ; \mathrm{M}=\mathrm{Cr}, \mathrm{Mn}, \mathrm{Fe}, \mathrm{Co}, \mathrm{Ni}, \mathrm{Cu}, \mathrm{Y}, \mathrm{Rh}, \mathrm{Ag}$, La, $\mathrm{Au}, \mathrm{Ga}]$ [8,12-20]. The structural and spectroscopic properties of corrole derivatives have been extensively investigated, both experimentally and theoretically. Among these metal corroles,

\footnotetext{
* Corresponding author. Tel: +86-411-84379673; Fax: +86-411-84685940; E-mail: jianlin@dicp.ac.cn

\# Corresponding author. Tel: +86-592-2186081; Fax: +86-592-2183047; E-mail: zxcao@xmu.edu.cn

This work was supported by the National Natural Science Foundation of China $(21663008,21763006,2193309,21963005,21878283,22022814)$, Natural Science Foundation of Guizhou Province of China ([2017]1029), and the Youth Innovation Promotion Association CAS (2017223). DOI: 10.1016/S1872-2067(20)63707-X | http://www.sciencedirect.com/science/journal/18722067 | Chin. J. Catal., Vol. 42, No. 6, June 2021
} 
manganese corroles have received considerable attention because of their excellent photoelectronic properties. Many studies have been conducted to investigate the oxidation state changes from + III to $+\mathrm{IV}$ and $+\mathrm{V}$ of manganese at the center of corrole and the effect of substituents mainly residing on the meso- $(5,10,15)$ and $\beta$ - $(2,3,7,8,12,13,17,18)$ positions of corrole $[1,21,22]$. In recent years, the formation of corrolazine through structural modification with the substitution of $\mathrm{N}$ atoms for the meso-C atoms of corrole has further increased the progress in the chemistry of the corroles.

High-valent metal-oxo species have been identified as key reactive intermediates in catalytic-selective oxidation reactions. Manganese corrolazines have the most common and stable pentavalent oxidation state of $\mathrm{Mn}(\mathrm{V})$, and are conveniently prepared by oxidation of $\mathrm{Mn}$ (III) corrolazines. It is important to develop transition-metal complexes that can directly utilize $\mathrm{O}_{2}$ in catalytic oxidations as an ideal oxidant because of its cost-effectiveness and cleanliness. To the best of our knowledge, this is the first report of the direct conversion of $\mathrm{Mn}(\mathrm{III})$ - to $\mathrm{Mn}(\mathrm{V})$-oxo corrolazine complex with $\mathrm{O}_{2}$ under visible-light irradiation [23]. Prokop and Goldberg [23] and our density functional theory (DFT) calculations [24] showed that a free-radical-like Mn-0-O is generated during the reaction of Mn-corrolazine with $\mathrm{O}_{2}$ under visible light irradiation, which exhibits excellent activity to the formation of a high-valent $\mathrm{Mn}(\mathrm{V})$-oxo active oxidant by abstracting hydrogen from the substrate followed by a rebound reaction [25]. Furthermore, a new activation mechanism of $\mathrm{O}_{2}$ was proposed, in which the $d_{x z}$ and $d_{y z}$ orbitals of Mn with a single electron can couple with $\pi_{x z}^{3}$ and $\pi_{y z}{ }_{2}^{3}$ of $\mathrm{O}_{2}$, respectively, to form two new extended $\pi$ bonds perpendicular to each other, $\pi_{x z}^{4}$ and $\pi_{y z}^{4}$ leading to an increase in the $0-0$ bond length and the weakening of the $0-0$ bond strength.

Two-dimensional (2D) nanomaterials have attracted significant interest in catalytic and photoelectric fields owing to their unique physical and chemical properties [26-30]. However, there is no report on the heterogeneous formation of homogeneous metal corrole catalysts into 2D nanocatalytic materials to expand their practical applications. Thus, to construct 2D nanocatalytic materials with high catalytic activity in which each metal atom acts as a single-atom catalyst (SAC) center [31-49], we selected linear ethynes as bridging groups to construct meso- and $\beta$-linked corrolazine dimers and tetramer [50]. Furthermore, a two-dimensional (2D) planar Mn-corrolazine nanocatalytic material can be constructed by extending the basic units of the Mn-corrolazine dimer along its two axes direction. Extensive first-principle calculations were performed to investigate their electronic properties, structural stabilities, energy density of states (DOS), and the possible activation mechanism for the selective oxidation process: $\mathrm{C}_{n} \mathrm{H}_{2 n+2}$ $+[\mathrm{Mn}(\mathrm{III})]-\mathrm{O}-\mathrm{O} \rightarrow \mathrm{Mn}(\mathrm{V})$-oxo $+\mathrm{C}_{n} \mathrm{H}_{2 n+1} \mathrm{OH}$ as well as its external electric field regulation mechanism. The present study theoretically designed and predicted a novel class of Mn-corrolazine-based 2D nanocatalytic materials with excellent catalytic properties that are easily regulated by the external electric field, and provides the fundamental basis for further experimental studies and practical applications of the
Mn-corrolazine in heterogeneous catalysis.

\section{Computational details}

Calculations of the structural and electronic properties of Mn-corrolazine polymers were performed using the Gaussian 09 package [51]. The B3LYP hybrid functional [52,53] in combination with the effective core potential coupled with the LANL2DZ basis set for manganese and the all-electron 6-31G(d) basis set for other atoms has been used for DFT calculations [51]. Frequency calculations were used to assess the nature of the stationary points on the potential-energy surfaces (PESs) and estimate their thermodynamic properties.

The structural and electronic properties of the 2D Mn-corrolazine nanomaterial were calculated using the Vienna $a b$ initio simulation package (VASP) [54,55]. The generalized gradient approximation (GGA) with the PBE functional was employed to describe the electron-exchange-correction potential in all calculations. The projector augmented wave (PAW) method was used to describe the electron-ion interaction, and the cutoff energy was set to $500 \mathrm{eV}$. The calculations were carried out with the DFT+U method, using the formalism suggested by Dudarev et al. [56]. The parameters were set at $U=4.0 \mathrm{eV}$ and $J=1.0 \mathrm{eV}$. All atomic positions were optimized by the conjugated gradient method with a converging tolerance of 0.02 $\mathrm{eV} / \AA ̊$ for the force on all atoms. Periodic boundary conditions are considered along with the growth directions of the nanomaterials. A vacuum distance over $15 \AA$ was set to maintain the negligible interaction between the periodic nanostructures in the adjacent cells. A $5 \times 5 \times 1$ Monkhorst-Pack grid was used for geometry optimization. The Brillouin zone was sampled by 21 $k$-points using Heyd-Scuseria-Ernzerhof (HSE06) screened Coulomb hybrid density functional [57-59] to calculate the electronic band structures and DOS of 2D Mn-corrolazine nanomaterials. The activation energy of $\mathrm{C}-\mathrm{H}$ bonds was also corrected by the dispersion correction using the approach of the DFT-D3 method as implemented in VASP 5.3.5 [60], and further external electric field effects on the $\mathrm{C}-\mathrm{H}$ bond activation were investigated at the same level of theory based on the optimized structures.

\section{Results and discussion}

\subsection{Structural and electronic properties of the Mn-corrolazine polymers}

Considering that the $\beta$ - positions of corrolazine and metallocorrolazines are the active sites and the structures with substituents at these sites are much more stable and robust, a series of $\beta$-to- $\beta$ ethyne-linked Mn-corrolazine polymers and 2D $\mathrm{Mn}$-corrolazine nanocatalytic materials (2D-Mncor) were constructed herein (Scheme 1). As shown in Scheme 1, the order of Mn-corrolazine rings is marked as $\mathrm{Mn}_{1}$ and $\mathrm{Mn}_{2}$ in the Mn-corrolazine dimer (di-Mn $\mathrm{M}_{\mathrm{cor}}$ ), and it is clockwise marked by $\operatorname{Mn}_{N}(N=1,2, \ldots)$ in the Mn-corrolazine tetramer (tetra- $\mathrm{Mn}_{\text {cor }}$ ). The optimized stable geometries without any imaginary frequency, selected bond lengths, and Mulliken charges of Mn of 


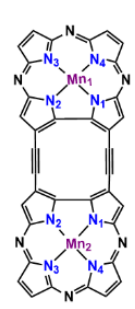

di-Mn $\mathrm{Mor}_{\text {}}$

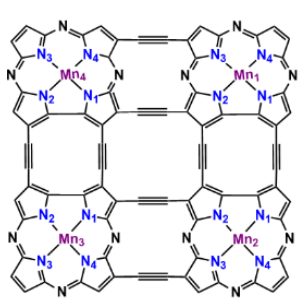

tetra- $\mathrm{Mn}_{\text {cor }}$

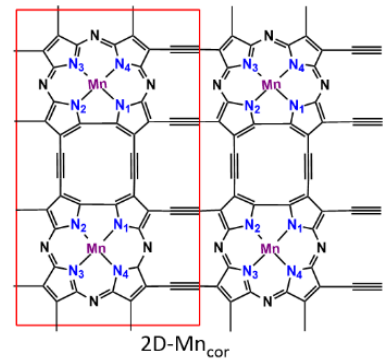

Scheme 1. Manganese corrolazine dimer $\left(\mathrm{di}-\mathrm{Mn}_{\mathrm{cor}}\right)$, tetramer (tetra- $\left.\mathrm{Mn}_{\text {cor }}\right)$ and their extended two-dimensional nanocatalytic material (2D-Mn $\mathrm{n}_{\text {cor }}$ ) constructed by combining Mn-corrolazines and ethynes.

the lowest singlet and nonet states for the Mn-corrolazine dimer and the singlet and 17-et states for the Mn-corrolazine tetramer are displayed in Fig. 1 and Fig. S1, and Table S1, respectively. As shown in Fig. 1(a) and (b), the optimized geometries of the dimer in the singlet ( $C_{s}$ symmetry) and nonet $\left(D_{2 h}\right.$ symmetry) states are quite similar. The singlet state is higher in energy than the nonet state by $98.65 \mathrm{kcal} / \mathrm{mol}$, and the nonet state is thus the ground state. Furthermore, the optimized geometries of the tetramer in the singlet ( $\mathrm{C}_{1}$ symmetry) and 17-et $\left(\mathrm{C}_{1}\right.$ symmetry) states are slightly distorted, as shown in Figs. $1(c)$ and (d). The singlet state of the tetramer is higher in energy than the 17 -et states by $194.38 \mathrm{kcal} / \mathrm{mol}$, and thus the 17 -et state is the ground state. These results are in agreement with those of previous studies $[24,61]$ in the fact that Mn-corrolazine exhibits a paramagnetic ground state, suggesting that the polymerization of corrolazine rings does not affect the electronic configuration of the central $\mathrm{Mn}$ atom, which is very favorable for constructing 2D materials with enhanced catalytic activity.

As seen in Table 1, the bond lengths of $\mathrm{Mn}-\mathrm{N}$ in the nonet ground state of di- $\mathrm{Mn}_{\text {cor }}$ and 17-et ground state of tetra- $\mathrm{Mn}_{\text {cor }}$ complexes are 1.860-1.864 and 1.865-1.880 $\AA$, respectively. To evaluate the stability of the nonet state of di-Mncor, 17 -et state of tetra- $\mathrm{Mn}_{\mathrm{cor}}$, the binding energies $(B E S)$ were calculated as:

$B E_{\mathrm{di}-\mathrm{Mn}_{\text {cor }}}=2 E_{\mathrm{HC} \equiv \mathrm{CH}}+2 E_{\mathrm{Mn}-\text { cor }}-E_{\mathrm{di}-\mathrm{Mn}_{\text {cor }}}-4 E_{\mathrm{H}_{2}}$

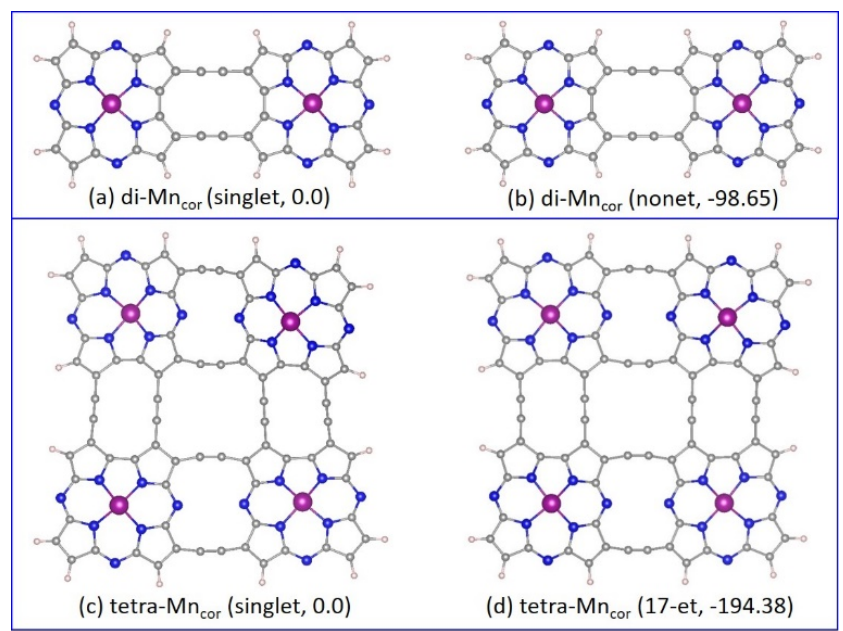

Fig. 1. Optimized geometries and relatively energies (kcal/mol) of di- $\mathrm{Mn}_{\text {cor }}$ in (a) singlet and (b) nonet states; tetra- $\mathrm{Mn}_{\text {cor }}$ in (c) singlet and (d) 17-et states (top view).
Table 1

Selected optimized bond lengths $(\AA)$, Mulliken spin densities $\left(\rho_{\text {spin }}\right)$ of $\mathrm{Mn}$, magnetic moment $\left(\mu_{B}\right)$, and relative energies $(\Delta E, \mathrm{kcal} / \mathrm{mol})$ of $\mathrm{Mn}(\mathrm{III})$-corrolazine in di- $\mathrm{Mn}_{\text {cor }}$ in the singlet and nonet states, tetra- $\mathrm{Mn}_{\text {cor }}$ in the single and 17 -et states, $2 \mathrm{D}-\mathrm{Mn}_{\text {cor }}$ with ferromagnetism (FM) and antiferromagnetism (AFM).

\begin{tabular}{lccccc}
\hline $\begin{array}{l}\text { Polymer } \\
\text { (State) }\end{array}$ & $\begin{array}{c}d_{\mathrm{Mn}-\mathrm{N} 1} \\
d_{\mathrm{Mn}-\mathrm{N} 2}\end{array}$ & $\begin{array}{c}d_{\mathrm{Mn}-\mathrm{N} 3} \\
d_{\mathrm{Mn}-\mathrm{N} 4}\end{array}$ & $d_{c \equiv c}$ & $\Delta E$ & $\begin{array}{c}\rho_{\text {spin }} / \mu_{B} \\
\mathrm{Mn}\end{array}$ \\
\hline Di-Mn $_{\text {cor }}$ & $1.864,1.864$ & $1.860,1.861$ & 1.218, & 0.0 & $3.77,3.77$ \\
(nonet) & $1.864,1.864$ & $1.860,1.861$ & 1.218 & & \\
Di-Mn $_{\text {cor }}$ & $1.848,1.848$ & $1.863,1.863$ & 1.218, & 98.65 & - \\
(singlet) & $1.848,1.848$ & $1.863,1.862$ & 1.218 & & - \\
Tetra-Mn & $1.865,1.878$ & $1.868,1.867$ & 1.215, & 0.0 & $3.77,3.77$ \\
(17-et) & $1.866,1.879$ & $1.868,1.867$ & 1.222 & & $3.77,3.77$ \\
& $1.866,1.880$ & $1.868,1.867$ & 1.215, & & \\
& $1.866,1.878$ & $1.868,1.866$ & 1.223 & & \\
& & & 1.216, & & \\
& & & 1.224 & & \\
Tetra-Mn & $1.847,1.856$ & $1.865,1.865$ & 1.216, & 194.38 & - \\
(singlet) & $1.847,1.856$ & $1.865,1.865$ & 1.222 & & \\
& $1.847,1.856$ & $1.865,1.865$ & 1.216, & & \\
& $1.848,1.856$ & $1.865,1.865$ & 1.222 & & \\
& & & 1.217, & & \\
& & & 1.224 & & \\
& & & 1.217, & & \\
2D-Mn & & & 1.224 & & \\
(FM) & $1.903,1.904$ & $1.885,1.886$ & 1.230, & 13.34 & $3.57,3.57$ \\
2D-Mn & $1.903,1.904$ & $1.885,1.886$ & 1.231 & & \\
(AFM) & $1.903,1.904$ & $1.885,1.886$ & 1.231, & 0.0 & 3.65, \\
\hline & $1.903,1.905$ & $1.885,1.887$ & 1.231 & & -3.65 \\
\hline
\end{tabular}

$B E_{\text {tetra }-\mathrm{Mn}_{\text {cor }}}=8 E_{\mathrm{HC} \equiv \mathrm{CH}}+4 E_{\mathrm{Mn}-\text { cor }}-E_{\text {tetra }-\mathrm{Mn}_{\text {cor }}}-16 E_{\mathrm{H}_{2}}(2)$ where $E[\cdot]$ are the total energies of the ethyne bridges, the $\mathrm{Mn}$-corrolazine ring, the di-Mncor, tetra- $\mathrm{Mn}_{\text {cor, }}$ and the hydrogen molecules.

The calculated $B E$ of $0.42 \mathrm{eV}$ suggests that the formation of the ground state di- $\mathrm{Mn}_{\text {cor }}$ is exothermic and energetically stable. With the increase of Mn-corrolazine rings in the ground state tetra- $\mathrm{Mn}_{\mathrm{cor}}$, the $B E$ is $1.11 \mathrm{eV}$, suggesting that the structure becomes more stable with an increase in the number of Mn-corrolazine rings and the ethyne bridges. Furthermore, in the dimer, two Mn-corrolazine rings linked by ethyne at the $\beta$ $(2,18)$ positions form a planar 12 -numbered conjugated ring, which benefits the stabilization of the dimer according to previous studies $[62,63]$. In tetra- $\mathrm{Mn}_{\mathrm{cor}}$, there are multiple macrocycles without the metal center, including two 12-membered $\mathrm{C}_{12}$ rings, one 16-membered $\mathrm{C}_{16}$ ring, and two 14-membered $\mathrm{C}_{12} \mathrm{~N}_{2}$ rings. The $\mathrm{C}_{12} \mathrm{~N}_{2}$ ring is composed of $\beta$-C atoms, $\beta$ - $\mathrm{CH}$ groups, meso-N atoms of corrolazine, and $-\mathrm{C} \equiv \mathrm{C}$ - bridging groups. The areas defined by the lengths and widths of $\mathrm{C}_{12}, \mathrm{C}_{16}$, and $\mathrm{C}_{12} \mathrm{~N}_{2}$ rings in the complex are ca. $5.79 \times 3.66,6.14 \times 5.27$, and $5.41 \times 3.87 \AA^{2}$, respectively. Because these polymers have pores with different sizes to accommodate numerous suitable reactive species, it is highly likely to construct an excellent platform for chemical reactions [64]. Mulliken population analysis revealed that the spin densities of the single Mn atoms in the nonet state (see Table 1) of di- $\mathrm{Mn}_{\text {cor }}$ and the 17-et state of tetra- $\mathrm{Mn}_{\text {cor }}$ are approximately 3.77 , which indicates that all $\mathrm{Mn}$ atoms have nearly all of the unpaired four electrons, respec- 
tively. Mn atoms in these polymers remain in their single-atom catalytic center for the reaction as in the monomer.

As shown in Fig. 2, similar to the monomer of Mn-corrolazine [24], the energy level of the $d_{x y}$ orbital of central $\mathrm{Mn}$ in the ground state di-Mncor is the highest among all $d$ orbitals of manganese because of the strong repulsion originating from the direct coordination interaction of four $\mathrm{N}$ atoms of the corrolazine ring. The lowest orbital is the $d_{x^{2}-y^{2}}$ orbital owing to weak coordination interactions because its stretching direction comes from the four $\mathrm{N}$ atoms of the corrolazine ring. The energy levels of the $d_{z^{2}}, d_{x z}$, and $d_{y z}$ orbitals are between the two orbitals mentioned above, resulting from no direct interaction with the atoms of the corrolazine ring. The energy level of $d_{z^{2}}$ is slightly higher owing to its small distribution in the corrolazine ring plane, and both $d_{x z}$ and $d_{y z}$ are approximately degenerate because of the only difference in their directions of space extension. Thus, the trivalent $\mathrm{Mn}$ atoms in these ground-state polymers still remain in the $d_{x^{2}-y^{2}}^{1} d_{x z}^{1} d_{y z}^{1} d_{z^{2}}^{1}$ configuration as in the monomer.

\subsection{Activation of $\mathrm{O}_{2}$ on $\mathrm{Mn}$-corrolazine polymers}

From the above results, the single electrons of di-Mncor in its nonet ground state mainly reside in two individual $\mathrm{Mn}$ atoms, and thus can form weak interaction complexes with the ground state ${ }^{3}\left[\mathrm{O}_{2}\right]$ through two spin alignments, respectively, as shown in Figs. 3(b) and (c). The spin reverse combination between the nonet di- $\mathrm{Mn}_{\text {cor }}$ and two triplet ${ }^{3}\left[\mathrm{O}_{2}\right]$ forms a quintet di-O- $\mathrm{Mn}_{\text {cor }}$ with four spin-up single electrons, in which the spin densities are 3.74 in two Mn atoms and $-0.92-(-1.03)$ in four oxygen atoms of the two adsorbed $\mathrm{O}_{2}$ (see Table 2). The bond lengths of $\mathrm{Mn}-\mathrm{N}$ and $\mathrm{O}-\mathrm{O}$ in quintet di-O-Mn $\mathrm{Mn}_{\text {cor }}$ are 1.871-1.874 and $1.216 \AA$, respectively. The distance between the $\mathrm{Mn}$ and $\mathrm{O}$ atoms is elongated up to 2.502-2.503 $\AA$. The other spin parallel combination between the nonet di- $\mathrm{Mn}_{\text {cor }}$ and two triplet ${ }^{3}\left[\mathrm{O}_{2}\right]$

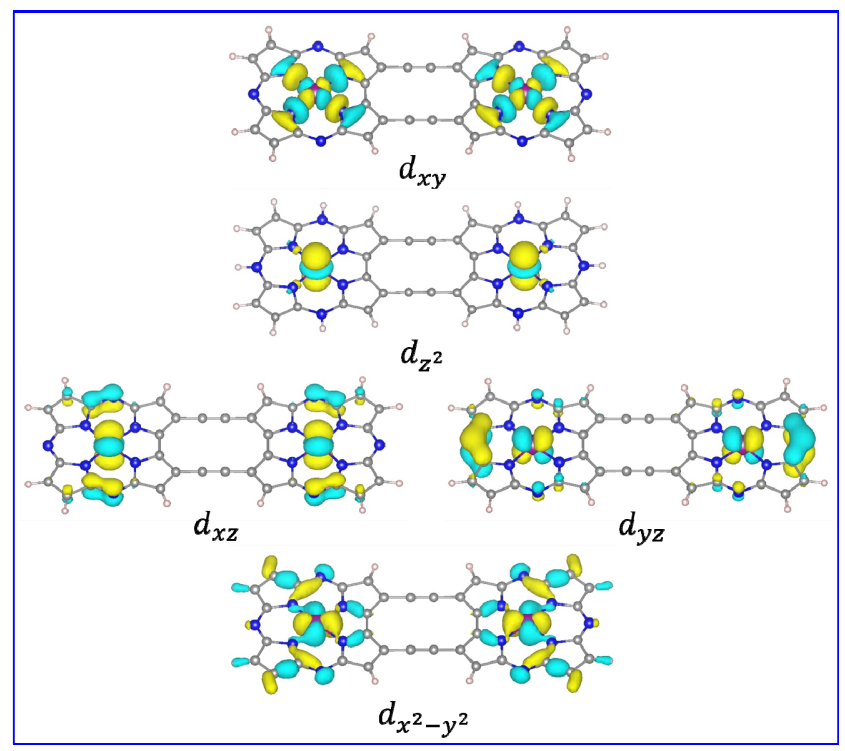

Fig. 2. Selected Mn-dominated molecular orbitals of the di-Mncor in the nonet state.

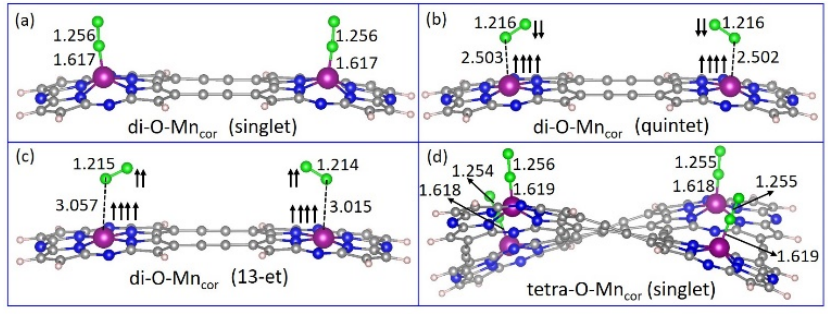

Fig. 3. Optimized geometries of di-O- $\mathrm{Mn}_{\text {cor }}$ complexes consisting of $\mathrm{O}_{2}$ and di-Mn $\mathrm{M}_{\text {cor }}$ in (a) singlet, (b) quintet, and (c) 13-et states. (d) Tetra- $\mathrm{O}-\mathrm{Mn}_{\text {cor }}$ in the singlet state consisting of $\mathrm{O}_{2}$ and tetra- $\mathrm{Mn}_{\text {cor }}$ with specific bond lengths $(\AA)$.

forms a 13-et di-O-Mn $\mathrm{M}_{\text {cor }}$ with net 12 spin-up single electrons, in which the spin densities are 3.77 in two Mn atoms and 0.98-1.03 in four oxygen atoms of the two adsorbed $\mathrm{O}_{2}$, and the bond lengths of Mn-N and O-O are 1.864-1.868 and 1.214 $\AA$, respectively. The distance between $\mathrm{Mn}$ and $\mathrm{O}$ atoms is even longer, up to $3.015-3.057 \AA$. As the di- $\mathrm{Mn}_{\text {cor }}$ and $\mathrm{O}_{2}$ moieties are far apart in both quintet and 13-et complexes, their interactions are very weak and they are almost isoenergetic with only an energy difference of $2.98 \mathrm{kcal} / \mathrm{mol}$. The corresponding spin densities of the individual $\mathrm{Mn}$ atoms (see Table 2) are also similar, 3.74 and 3.77, respectively. The interconversion of both configurations is almost barrier-free, and these may act as precursors for the reaction of di- $\mathrm{Mn}_{\text {cor }}$ and $\mathrm{O}_{2}$.

As shown in Fig. 3(a), the bond length of Mn-O in the singlet

Table 2

The bond lengths of Mn-N $(\AA)$, the relative energies $(\Delta G, \mathrm{kcal} / \mathrm{mol})$ and Mulliken spin densities $\left(\rho_{\text {spin }}\right)$, selected atoms' magnetic moments $\left(\mu_{B}\right)$ of the complexes of $\mathrm{O}_{2}$ and $\mathrm{Mn}(\mathrm{III})$-corrolazine in different states of di-O-Mn $\mathrm{Mn}_{\text {cor }}$, tetra-O-Mn $\mathrm{Mn}_{\text {cor }}$ and $2 \mathrm{D}-\mathrm{Mn}_{\text {cor }}$.

\begin{tabular}{|c|c|c|c|c|c|c|c|}
\hline \multirow{2}{*}{$\begin{array}{l}\text { Polymer } \\
\text { (State) }\end{array}$} & \multirow{2}{*}{$\begin{array}{l}d_{\mathrm{Mn}-\mathrm{N} 1} \\
d_{\mathrm{Mn}-\mathrm{N} 2}\end{array}$} & \multirow{2}{*}{$\begin{array}{l}d_{\mathrm{Mn}-\mathrm{N} 3} \\
d_{\mathrm{Mn}-\mathrm{N} 4}\end{array}$} & \multirow{2}{*}{$d_{0-0}$} & \multirow{2}{*}{$\Delta E$} & \multicolumn{3}{|c|}{$\rho_{\text {spin }} / \mu_{B}$} \\
\hline & & & & & ${ }^{\mathrm{a}} \mathrm{O}$ & ${ }^{\mathrm{b}} \mathrm{O}$ & $\mathrm{Mn}$ \\
\hline Di-O-Mn & 1.867, & 1.865, & 1.214 & 0.0 & 1.03 & 0.98 & 3.77 \\
\hline (13-et) & $\begin{array}{l}1.868 \\
1.867, \\
1.868\end{array}$ & $\begin{array}{l}1.864 \\
1.864, \\
1.864\end{array}$ & 1.214 & & 1.03 & 0.98 & 3.77 \\
\hline Di-O-Mn & 1.874, & 1.871, & 1.216 & 2.98 & -1.03 & -0.92 & 3.74 \\
\hline (quintet) & $\begin{array}{l}1.874 \\
1.874, \\
1.873\end{array}$ & $\begin{array}{l}1.871 \\
1.871 \\
1.871\end{array}$ & 1.216 & & -1.03 & -0.92 & 3.74 \\
\hline $\begin{array}{l}\mathrm{Di}-\mathrm{O}-\mathrm{Mn}_{\text {cor }} \\
\text { (singlet) }\end{array}$ & $\begin{array}{l}1.871, \\
1.877 \\
1.873, \\
1.876\end{array}$ & $\begin{array}{l}1.899 \\
1.894 \\
1.896 \\
1.894\end{array}$ & $\begin{array}{l}1.256 \\
1.256\end{array}$ & 84.14 & - & - & - \\
\hline $\begin{array}{l}\text { Tetra-O- } \mathrm{Mn}_{\text {cor }} \\
\text { (singlet) }\end{array}$ & $\begin{array}{l}1.858, \\
1.897 \\
1.865, \\
1.894 \\
1.858, \\
1.897 \\
1.865, \\
1.894\end{array}$ & $\begin{array}{l}1.886, \\
1.894 \\
1.893 \\
1.898 \\
1.886 \\
1.894 \\
1.893 \\
1.898\end{array}$ & $\begin{array}{l}1.254 \\
1.255 \\
1.255 \\
1.256\end{array}$ & - & - & - & - \\
\hline $\begin{array}{l}\text { 2D-O-Mn } \mathrm{Mno}_{\text {}} \\
\text { (spin-polarized) }\end{array}$ & $\begin{array}{l}1.921, \\
1.923 \\
1.920 \\
1.921\end{array}$ & $\begin{array}{l}1.903 \\
1.902 \\
1.903 \\
1.904\end{array}$ & $\begin{array}{l}1.262 \\
1.262\end{array}$ & 0.0 & $\begin{array}{c}-0.73 \\
0.73\end{array}$ & $\begin{array}{c}-0.58 \\
0.57\end{array}$ & $\begin{array}{c}3.58 \\
-3.58\end{array}$ \\
\hline $\begin{array}{l}\text { 2D-O-Mn } \mathrm{Mn}_{\text {cor }} \\
\text { (spin-unpolarized) }\end{array}$ & $\begin{array}{l}1.925 \\
1.929 \\
1.927 \\
1.928\end{array}$ & $\begin{array}{l}1.917 \\
1.918 \\
1.917 \\
1.918\end{array}$ & $\begin{array}{l}1.267 \\
1.267\end{array}$ & 74.53 & - & - & - \\
\hline
\end{tabular}


state of di-O- $\mathrm{Mn}_{\text {cor }}$ is shorter than those in the quintet and 13-et states of di-O- $\mathrm{Mn}_{\text {cor }}$ by $0.885-0.886$ and $1.398-1.440 \AA$, respectively. This result suggests that there is a strong bonding interaction between $\mathrm{Mn}$ and $\mathrm{O}_{2}$ in the direction perpendicular to the corrolazine plane in the singlet complex, leading to the high-energy singlet complex. This structure is less stable than the quintet and 13-et states of di-O- $\mathrm{Mn}_{\text {cor }}$ by 40.58 and 42.07 $\mathrm{kcal} / \mathrm{mol}$ per unit, respectively. Such energy differences are in the visible range and are compatible with the mild Mn-corrolazine-catalyzed reaction condition of visible-light irradiation. Furthermore, the energy levels of $d_{z^{2}}$ Mn orbitals in the singlet state of di-O-Mncor significantly increase due to the strong interaction arising from the $\mathrm{O}_{2}$ ligand in the $z$ direction. Thus, the reaction of di-O- $\mathrm{Mn}_{\text {cor }}$ with $\mathrm{O}_{2}$ would undergo the electron spin-reverse process, where the weak interaction of the precursors, di-O- $\mathrm{Mn}_{\text {cor }}$ complexes in the quintet and 13-et states, may evolve into strong interactions by the spin-flip of electrons in high-energy $d_{z^{2}}$ orbitals and transfer to low-energy $d_{x^{2}-y^{2}}$ orbitals under visible-light irradiation, and the electronic configuration of $\mathrm{Mn}$ (III) changes from $d_{x^{2}-y^{2}}^{1} d_{x z}^{1} d_{y z}^{1} d_{z^{2}}^{1}$ to $d_{x^{2}-y^{2}}^{2} d_{x z}^{1} d_{y z}^{1}$ (as shown in Fig. 4).

In addition, similar to the Mn-corrolazine monomer, the

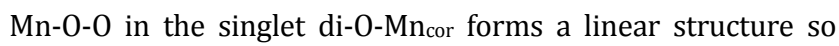
that two extended $\pi$ bonds $\pi_{x z}{ }_{3}^{4}$ and $\pi_{y z}{ }_{3}^{4}$ featuring free radicals are formed originating from $d_{x z}$ and $d_{y z}$ orbitals of Mn coupled with the $\pi_{x z 2}^{3}$ and $\pi_{y z}{ }_{2}^{3}$ of $\mathrm{O}_{2}$. Moreover, with an increase in the $\mathrm{Mn}(\mathrm{III})$-corrolazine rings, the $\mathrm{O}-\mathrm{O}$ and $\mathrm{Mn}-\mathrm{O}$ bond lengths of the singlet tetra- $\mathrm{O}-\mathrm{Mn}_{\text {cor }}$ complex consisting of the adsorbed $\mathrm{O}_{2}$ and the tetra-polymer (as shown in Fig. 3(d)) are almost the same as those of the singlet di-O-Mncor. The Mn-O-O moieties also form extended linear $\pi$ bonds with free radical characteristics, indicating that the increase of Mn(III)-corrolazine rings has little effect on the electronic properties of the polymers composed of Mn(III)-corrolazine rings and ethyne bridges. These results suggest that the reaction process between $\mathrm{Mn}$-corrolazine polymers and $\mathrm{O}_{2}$ did not change with the increase in the number of Mn(III)-corrolazine rings.

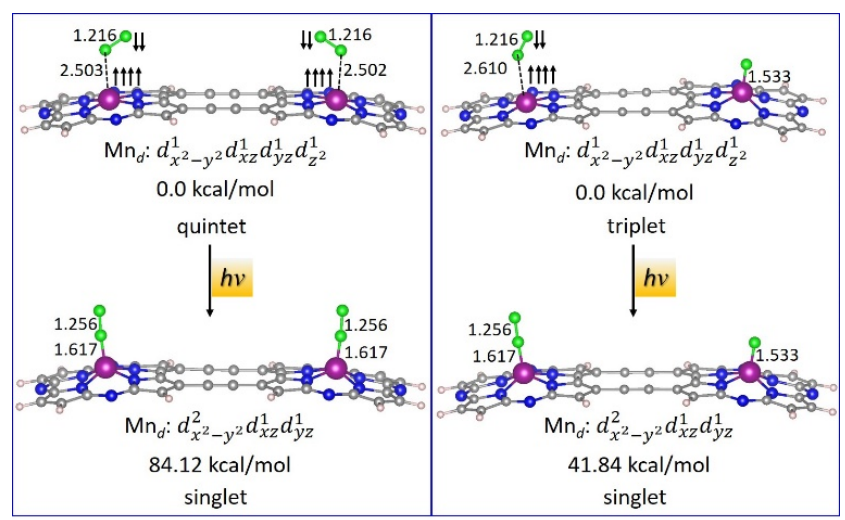

Fig. 4. The optimized structures of quintet-, triplet- and singlet-state complexes of $\mathrm{Mn}(\mathrm{III})$-corrolazine and ${ }^{3}\left[\mathrm{O}_{2}\right]$ and the energy difference between corresponding two complexes with different spin multiplicities.

\subsection{Structural, electronic properties, and stability of the $2 D$ Mn-corrolazine catalyst}

As discussed above, Mn-corrolazine polymers become more stable with increasing $\beta$-to- $\beta$-ethyne-linked Mn-corrolazine rings. These polymers have a highly ordered pore structure, which allows us to further extend the polymers explanation to two-dimensional (2D) nanomaterials. We use ethyne to link the units of di-Mncor by $\beta$-to- $\beta$ along its $x$ - and $y$-axial directions (as shown in Fig. 5(a)). The optimized stable structure and selected bond lengths of 2D-Mn $\mathrm{Mn}_{\text {cor }}$ are presented in Fig. 5(a) and Table 1. As seen in Fig. 5(a) and Table 1, the optimized structure of $2 \mathrm{D}-\mathrm{Mn}_{\mathrm{cor}}$ is planar, and the bond lengths of Mn-N (1.885-1.905 $\AA$ ) and $-\mathrm{C} \equiv \mathrm{C}-\left(1.231 \AA\right.$ ) in $2 \mathrm{D}-\mathrm{Mn}_{\text {cor }}$ are quite similar to those of

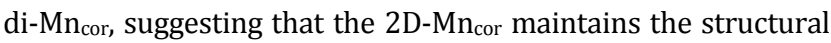
properties of the Mn-corrolazine polymers. Moreover, the electronic spin densities of the $2 \mathrm{D}-\mathrm{Mn}_{\text {cor }}$ (Fig. S2) are mainly distributed on the individual $\mathrm{Mn}$ atoms, in which the calculated magnetic moments of two individual $\mathrm{Mn}$ atoms in the unit cell of $2 \mathrm{D}-\mathrm{Mn}_{\text {cor }}$ are 3.65 and $-3.65 \mu_{\mathrm{B}}$ (Table 1 ). This indicates that $\mathrm{Mn}$ atoms in the 2D nanomaterial still remain in the active center for the reaction as in the monomer.

Similar to the di- $\mathrm{Mn}_{\text {cor }}$ and tetra- $\mathrm{Mn}_{\text {cor }}$ complexes, there are also many pores of 12 -membered $\mathrm{C}_{12}$, 16 -membered $\mathrm{C}_{16}$, and

(a)

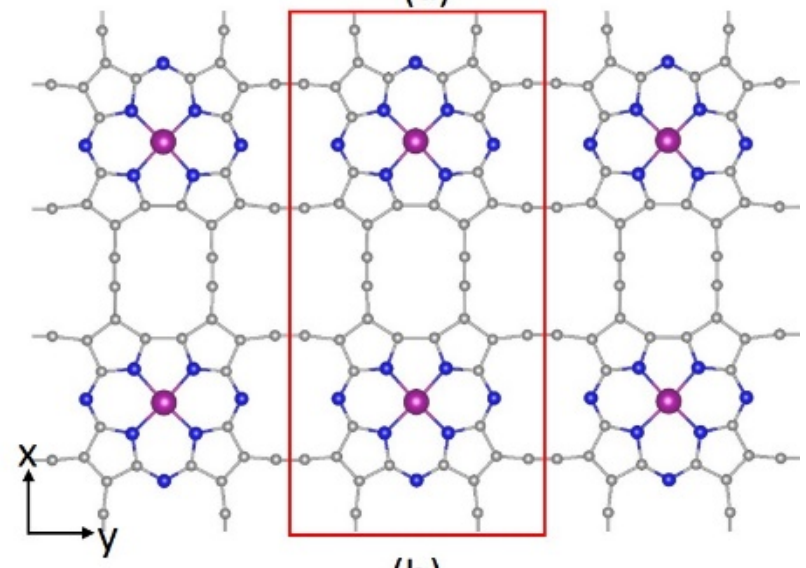

(b)

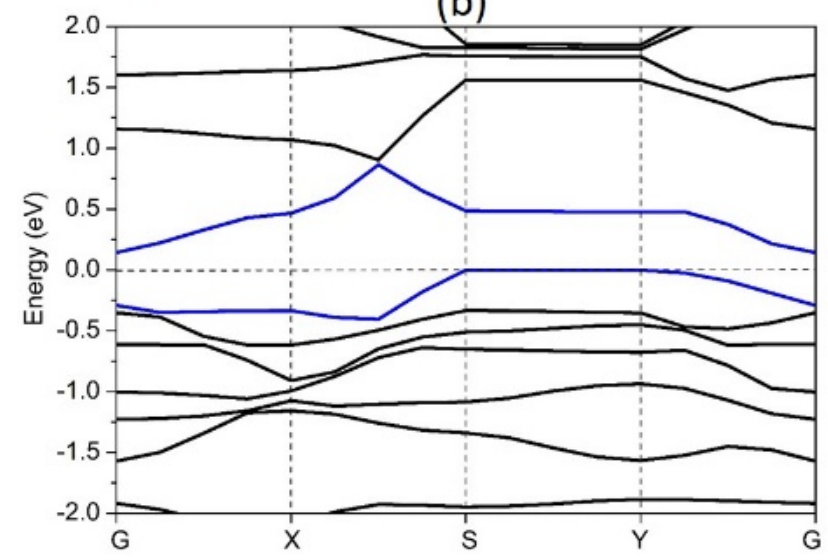

Fig. 5. (a) Optimized geometry and (b) the electronic band structure of $2 \mathrm{D}-\mathrm{Mn}_{\text {cor }}$ nanomaterial 
14-membered $\mathrm{C}_{12} \mathrm{~N}_{2}$ in the $2 \mathrm{D}-\mathrm{Mn}_{\text {cor }}$ nanomaterial, with sizes of ca. $5.65 \times 4.13,6.57 \times 5.42$, and $5.28 \times 4.11 \AA^{2}$, respectively. These pores with different sizes allow the corresponding molecules to cross the plane of this novel $2 \mathrm{D}-\mathrm{Mn}_{\text {cor }}$ nanomaterial, which may facilitate the reaction of molecules on its surface. In addition, the $2 \mathrm{D}-\mathrm{Mn}_{\text {cor }}$ nanomaterial is actually a semiconductor with a precise band gap of $0.14 \mathrm{eV}$ predicted by HSE06 in Fig. 5(b) and by pure PBE in Fig. S3, in which each Mn center retains its independent single-atom catalytic activity during the reaction. Thus, the $2 \mathrm{D}-\mathrm{Mn}_{\text {cor }}$ nanomaterial is likely to be an excellent platform for catalytic reactions.

\subsection{Activation of the $\mathrm{C}-\mathrm{H}$ bond on the $2 \mathrm{D}$ Mn-corrolazine catalyst}

Fig. $\mathrm{S} 4$ shows that once $\mathrm{O}_{2}$ is adsorbed on the $2 \mathrm{D}-\mathrm{Mn}_{\text {cor }}$, stable spin-polarized $2 \mathrm{D}-\mathrm{O}-\mathrm{Mn}_{\text {cor }}$ is formed. The $2 \mathrm{D}-\mathrm{Mn}_{\text {cor }}$ moiety in the optimized 2D-O-Mncor remains approximately planar, except for the slightly upward out-of-plane distortion of $\mathrm{Mn}$ atoms due to their interactions with the adsorbed $\mathrm{O}_{2}$. As shown in Table 2, the calculated magnetic moments of the two Mn atoms in $2 \mathrm{D}-\mathrm{O}-\mathrm{Mn}_{\text {cor }}$ are 3.58 and $-3.58 \mu_{\mathrm{B}}$, respectively, and the electronic spin densities of 2D-O-Mn $\mathrm{M}_{\text {cor }}$ (Fig. S2) are mainly distributed on the Mn atoms and adsorbed $\mathrm{O}_{2}$.

Similar to di-O- $\mathrm{Mn}_{\text {cor, }} 2 \mathrm{D}-\mathrm{O}-\mathrm{Mn}_{\text {cor }}$ also has a high-energy spin-unpolarized state in which the $\mathrm{O}_{2}$ molecule can form the radical-like [Mn]-O-O with the central $\mathrm{Mn}$ atom of $2 \mathrm{D}-\mathrm{Mn}_{\text {cor, }}$ as shown in Fig. S4. The 0-0 bond length increases from $1.205 \AA$ in the free oxygen molecule to $1.267 \AA$ in its adsorbed state, indicating that the $\mathrm{O}_{2}$ molecule is significantly activated and the $\mathrm{Mn}$ atoms in the 2D nanomaterial can act as catalytic centers for the activation of $\mathrm{O}_{2}$. Moreover, as shown in Table 2, the energy of the spin-unpolarized state is higher than that of the spin-polarized state by $37.27 \mathrm{kcal} / \mathrm{mol}$ per [Mn]-0-0 unit, which is again in the visible-light range (accessible with visible light irradiation). This suggests that the Mn-corrolazine catalyst is photo-triggered under mild conditions.

Here, we investigated the catalytic performance of the [Mn]-O-O moiety of $2 \mathrm{D}-\mathrm{O}-\mathrm{Mn}_{\text {cor }}$ in the spin-unpolarized state towards the activation of C-H bonds [65-67], which is one of the most important topics in catalysis. We first explored the selective conversion of cyclohexane into cyclohexanol, in which

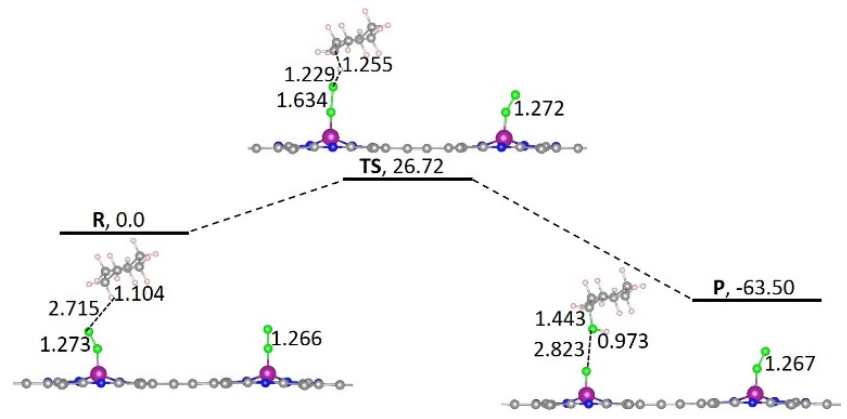

Fig. 6. The predicted reaction pathway for the generation of cyclohexanol and the $\mathrm{Mn}(\mathrm{V})$-oxo unit catalyzed by the $2 \mathrm{D}-\mathrm{O}-\mathrm{Mn}_{\text {cor }}$ nanomaterial in the spin-unpolarized state (relative energies and selected bond lengths are in $\mathrm{kcal} / \mathrm{mol}$ and $\AA$, respectively). one $\mathrm{C}-\mathrm{H}$ bond is converted by oxidation. Similar to the Mn-corrolazine monomer, the [Mn]-O-O moiety of $2 \mathrm{D}-\mathrm{O}-\mathrm{Mn}_{\text {cor }}$ selectively converts cyclohexane to cyclohexanol through $\mathrm{H}$-abstraction and rebound reaction processes [25,68]. Fig. 6 presents the relative energy profiles for the reaction steps (3) and (4), along with the optimized structures of reactant (R), transition state (TS), and product (P). Since the rebound step from the newly generated radical is very fast, it will merge into the $\mathrm{H}$-abstraction process, and the selective oxidation of cyclohexane to cyclohexanol is similar to the oxygen insertion reaction. As shown in Fig. 6, the selective oxidation process is remarkably exothermic by $63.5 \mathrm{kcal} / \mathrm{mol}$ with an activation energy of $26.72 \mathrm{kcal} / \mathrm{mol}$, which indicates that the [Mn]-0-O moiety of the $2 \mathrm{D}-\mathrm{O}-\mathrm{Mn}_{\text {cor }}$ nanomaterial maintained a high catalytic activity, similar to its monomer.

$$
\mathrm{C}_{6} \mathrm{H}_{12}+[\mathrm{Mn}(\mathrm{IV})]-\mathrm{O}-\mathrm{O} \rightarrow[\mathrm{Mn}(\mathrm{V})]-\mathrm{O}---\mathrm{OH}+\mathrm{C}_{6} \mathrm{H}_{11} \text {. }
$$$$
[\mathrm{Mn}(\mathrm{V})]-\mathrm{O}---\mathrm{OH}+\mathrm{C}_{6} \mathrm{H}_{11} \cdot \rightarrow \mathrm{Mn}(\mathrm{V})-\mathrm{Oxo}+\mathrm{C}_{6} \mathrm{H}_{11} \mathrm{OH}
$$

Considering the high activity of the [Mn]-0-O moiety of the 2D-O- $\mathrm{Mn}_{\text {cor }}$ nanomaterial, we further investigated its catalytic performance in the direct conversion of methane into methanol [69-71]. The reaction pathway for the activation and oxidation of $\mathrm{CH}_{4}$ by the 2D-O-Mncor nanomaterial through the $\mathrm{H}$-abstraction and rebound steps (5) and (6) is proposed; the predicted relative energies and the optimized structures of reactant (R), transition state (TS), and product (P) are shown in Fig. 7. In the first step of $\mathrm{CH}_{4}$ activation from the initial structure (Fig. 7), the $\mathrm{H}$ abstraction from $\mathrm{CH}_{4}$ by the terminal $\mathrm{O}$ of the radical-like [Mn]-O-O species leads to the [Mn]-O-OH intermediate (Int) and the $\mathrm{CH}_{3} \cdot$ free radical, with an activation energy of $34.96 \mathrm{kcal} / \mathrm{mol}$. The distance between the terminal 0 and the abstracted $\mathrm{H}$ varies from 2.643 to $1.198 \AA$, and the $0-0$ bond length of the adsorbed $\mathrm{O}_{2}$ increases from 1.271 to $1.674 \AA$ at the same time, resulting in the formation of $\mathrm{OH}$ between the free radical $\mathrm{CH}_{3} \cdot$ and $[\mathrm{Mn}(\mathrm{V})]-\mathrm{O}$. Thereafter, the rebound reaction $[25,68]$ immediately occurs in the second step, which is essential in the formation of methanol; the $\mathrm{OH}$ species rapidly rebounds to $\mathrm{CH}_{3}$, which produces the $\mathrm{Mn}(\mathrm{V})$-oxo corrolazine nanomaterial and $\mathrm{CH}_{3} \mathrm{OH}$. Because of the high reaction rate of $\mathrm{OH}$ rebounding to the substrate radical $\mathrm{CH}_{3} \cdot$, the $\mathrm{CH}_{3} \cdot$ radical has insufficient time to leave the Mn-O---OH moiety, selectivity leading to a highly specific and stable methanol product. Similarly, the facile rebound step initiates the H-abstraction process, as for the selective oxidation of cyclohexane. Moreover,

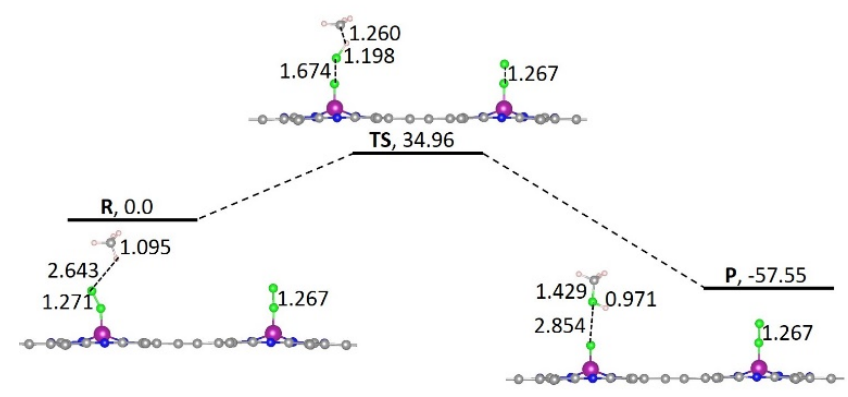

Fig. 7. Proposed reaction pathway for $\mathrm{CH}_{4}$ activation on the $2 \mathrm{D}-\mathrm{O}-\mathrm{Mn}_{\text {cor }}$ nanomaterial in the spin-unpolarized state (relative energies and selected bond lengths are in $\mathrm{kcal} / \mathrm{mol}$ and $\AA$, respectively). 


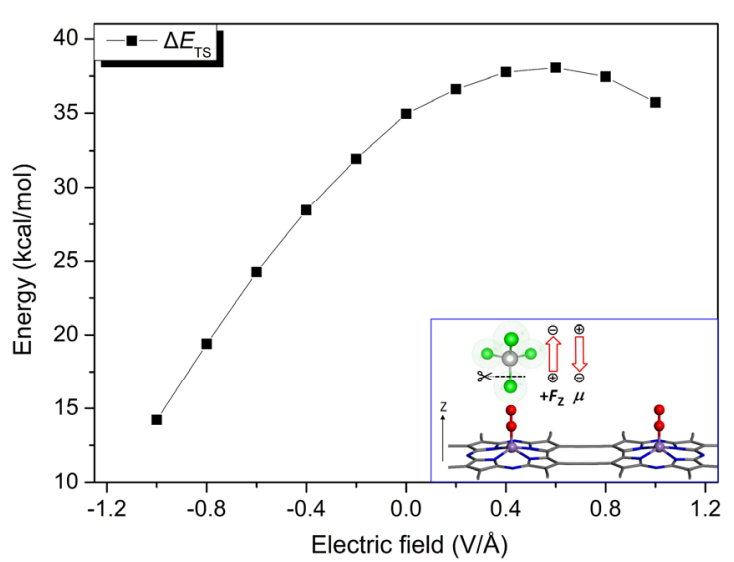

Fig. 8. Predicted barriers for the conversion of $\mathrm{CH}_{4}$ to $\mathrm{CH}_{3} \mathrm{OH}$ under various external electric fields.

the energy released in the $\mathrm{OH}$ formation and rebound reaction is as high as $57.55 \mathrm{kcal} / \mathrm{mol}$ with respect to the initial reactants, which provides the driving force for the overall reaction to the selective formation of methanol. Additionally, the rationality of the catalytic oxidation of alkanes to alcohol through the singlet potential energy surface and the possibility that the left oxygen atom on the catalyst further oxidizes the alkane to the alcohol is discussed in the supporting information, as shown in Figs. S5, S6, and S7.

$$
\begin{array}{r}
\mathrm{CH}_{4}+[\mathrm{Mn}(\mathrm{IV})]-\mathrm{O}-\mathrm{O} \rightarrow[\mathrm{Mn}(\mathrm{V})]-\mathrm{O}---\mathrm{OH}+\mathrm{CH}_{3} \cdot \\
{[\mathrm{Mn}(\mathrm{V})]-\mathrm{O}---\mathrm{OH}+\mathrm{CH}_{3} \cdot \rightarrow \mathrm{Mn}(\mathrm{V})-\mathrm{OxO}+\mathrm{CH}_{3} \mathrm{OH}}
\end{array}
$$

Overall, the Mn-corrolazine 2D nanomaterial can maintain the catalytic activity of the Mn-corrolazine molecular unit, where each Mn atom of the Mn-corrolazine rings can act as the SAC center to efficiently catalyze the direct conversion of highly stable methane to methanol by $\mathrm{O}_{2}$, which may possibly expand the applications of Mn-corrolazine-based catalysts in the industry.

\subsection{Effect of external electric field on the catalytic activity of $2 D$ Mn-corrolazine}

In comparison with the conversion of cyclohexane into cyclohexanol catalyzed by the Mn-corrolazine 2D nanomaterial, the activation energy for the catalytic conversion of methane into methanol has a higher activation energy of $34.96 \mathrm{kcal} / \mathrm{mol}$. To reduce the activation energy, the effect of an external electric field on the reaction was investigated.

External electric fields [72,73] have a great potential to regulate the reaction activity of various molecules, few-layer graphene (FLG), and ferromagnetism in thin-film semiconducting alloys. However, they need to achieve the difficult task of orienting the reactants and the external electric field along the reaction axis. the electronic reorganization from reactants to products results in enhancing the stability of ionic structures to facilitate catalytic reactions. For the $2 \mathrm{D}-\mathrm{Mn}_{\text {cor }}$ nanomaterial with high stability, its intrinsic reaction axis is always found to be along the Mn-O-O bond. Thus, it was quite easy to orient the reactants and the electric field along the reaction axis simultaneously, by aligning the external electric field with the Mn-0-O bond. Based on the optimized structures of $R$ and TS in Fig. 7, the external electric field effects on the $R$ and $T S$ energies were investigated theoretically. Fig. S8 shows that for $F_{z}>0$, the energy changes for $R$ and TS are similar, while for $F z<0$, the energy of $T S$ decreases more rapidly than that of $R$. Such discrepancies might be used for activity regulation with the aid of an external electric field. Accordingly, the electric field is oriented to the $z$-axis which is the reaction axis Mn-0-0, as shown in Fig. 8. For $F_{z}>0$, the reaction barrier increases slightly, while for $F_{z}$ $<0$, the reaction barrier decreases from 34.96 to 14.23 $\mathrm{kcal} / \mathrm{mol}$ when $F_{z}$ changes from 0 to $-1.0 \mathrm{~V} / \AA ̊$. Clearly, the oriented external electric field, along with its intrinsic reaction in the axis perpendicular to the material plane, can significantly decrease the activation energy and enhance the catalytic conversion of $\mathrm{CH}_{4}$.

\section{Conclusions}

In summary, we designed and systematically studied the Mn-corrolazine-based polymer and its 2D monolayer material for the catalytic conversion of alkanes to alcohols using ab initio calculations. The results show that the stability of these polymers increases with the integration of the Mn-corrolazine rings from di-Mn $\mathrm{Mn}_{\text {cor }}$ to tetra-Mn $\mathrm{Mn}_{\text {cor. }}$ Based on the Mn-corrolazine and $-\mathrm{C} \equiv \mathrm{C}$ - building blocks, a $2 \mathrm{D}$ nanocatalytic material, $2 \mathrm{D}-\mathrm{Mn}_{\mathrm{cor}}$, was constructed. Moreover, in these polymers and $2 \mathrm{D}-\mathrm{Mn}_{\text {cor }}$, there is a central $\mathrm{Mn}$ atom in each corrolazine ring, and the individual $\mathrm{Mn}$ atom maintains its electronic configuration with four single electrons, which can act as an excellent catalytic center. There are numerous pores with different sizes in $2 \mathrm{D}-\mathrm{Mn}_{\text {cor }}$ to allow suitable molecules to pass through the 2D framework. Thus, $2 \mathrm{D}-\mathrm{Mn}_{\text {cor }}$ can be an excellent reaction platform where each central $\mathrm{Mn}$ atom acts as a SAC center and activate $\mathrm{O}_{2}$ to form the radical-like [Mn]-0-O intermediate. The [Mn]-O-O free radical can activate the $\mathrm{C}-\mathrm{H}$ bond, which catalyzes the direct conversion of cyclohexane to cyclohexanol or methane to methanol through the $\mathrm{H}$-abstraction of $\mathrm{CH}_{4}$, followed by the rebound reaction. This selective oxidation of $\mathrm{CH}_{4}$ can be easily regulated by the external electric field along its intrinsic Mn-O-O reaction axis. The present study opens an alternative to heterogenize homogeneous catalysts and to improve their catalytic performance.

\section{Electronic supporting information}

Supporting information is available in the online version of this article.

\section{References}

[1] J. F. B. Barata, M. G. P. M. S. Neves, M. A. F. Faustino, A. C. Tomé, J. A. S. Cavaleiro, Chem. Rev., 2017, 117, 3192-3253.

[2] A. Ghosh, Chem. Rev., 2017, 117, 3798-3881.

[3] C. Zhu, J. Liang, B. Wang, J. Zhu, Z. Cao, Phys. Chem. Chem. Phys., 2012, 14, 12800-12806.

[4] P. Li, Z. Cao, Organometallics, 2018, 37, 406-414.

[5] Z. Gross, N. Galili, I. Saltsman, Angew. Chem. Int. Ed., 1999, 38, 


\section{Graphical Abstract}

Chin. J. Catal., 2021, 42: 1030-1039 doi: 10.1016/S1872-2067(20)63707-X

Mn-corrolazine-based 2D-nanocatalytic material with single Mn atoms for catalytic oxidation of alkane to alcohol

Chun Zhu, Jin-Xia Liang, Yang Meng, Jian Lin*, Zexing Cao *

Guizhou University; Guizhou Education University;

Dalian Institute of Chemical Physics, Chinese Academy of Sciences; Xiamen University

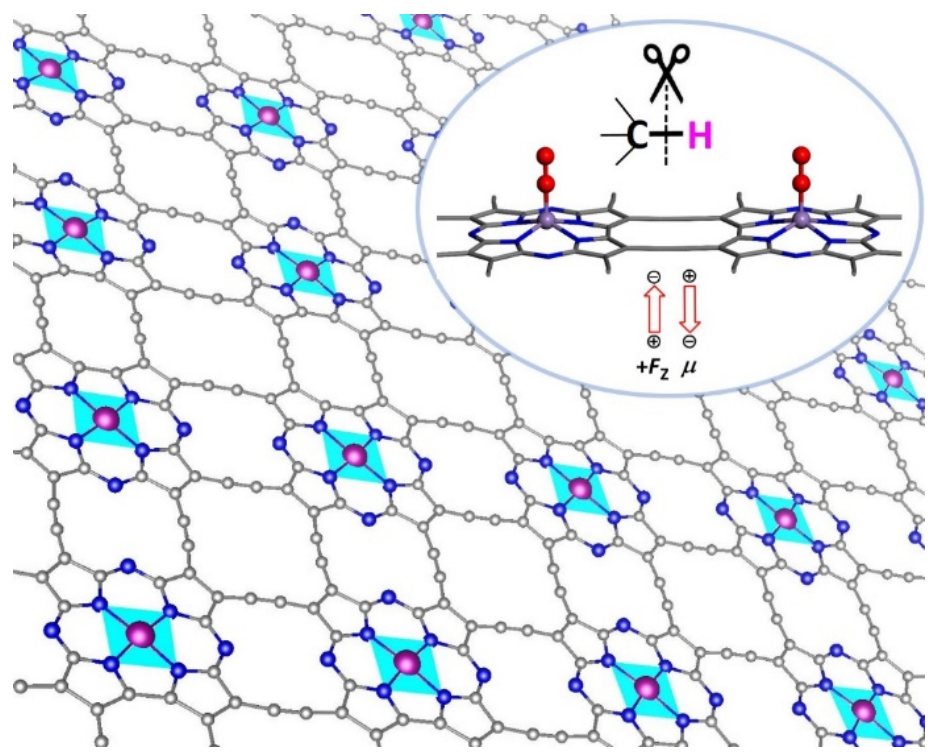

Novel two-dimensional (2D) Mn-corrolazine nanocatalytic materials bearing Mn atoms as single-atom catalyst centers can efficiently and selectively oxidize $\mathrm{C}-\mathrm{H}$ to $\mathrm{C}-\mathrm{OH}$ bonds through the regulation of an external electric field.

\section{7-1429.}

[6] I. Aviv-Harel, Z. Gross, Coord. Chem. Rev., 2011, 255, 717-736.

[7] H.-Y. Liu, M. H. R. Mahmood, S.-X. Qiu, C. K. Chang, Coord. Chem. Rev., 2013, 257, 1306-1333.

[8] A. Mahammed, Z. Gross, Coord. Chem. Rev., 2019, 379, 121-132.

[9] S. Nardis, F. Mandoj, M. Stefanelli, R. Paolesse, Coord. Chem. Rev., 2019, 388, 360-405.

[10] W. Liu, X. Huang, M.-J. Cheng, R. J. Nielsen, W. A. Goddard, J. T. Groves, Science, 2012, 337, 1322-1325.

[11] S. Leininger, B. Olenyuk, P. J. Stang, Chem. Rev., 2000, 100, 853-908.

[12] W. Nam, Acc. Chem. Res., 2007, 40, 522-531.

[13] G. Golubkov, J. Bendix, H. B. Gray, A. Mahammed, I. Goldberg, A. J. DiBilio, Z. Gross, Angew. Chem. Int. Ed., 2001, 40, 2132-2134.

[14] N. Wang, H. Zheng, W. Zhang, R. Cao, Chin. J. Catal., 2018, 39, 228-244.

[15] E. Vogel, S. Will, A. S. Tilling, L. Neumann, J. Lex, E. Bill, A. X. Trautwein, K. Wieghardt, Angew. Chem. Int. Ed., 1994, 33, 731-735.

[16] A. E. Meier-Callahan, H. B. Gray, Z. Gross, Inorg. Chem., 2000, 39, 3605-3607.

[17] G. Golubkov, Z. Gross, Angew. Chem. Int. Ed., 2003, 42, 4507-4510.

[18] C. Zhu, J.-X. Liang, J. Power Sources, 2015, 283, 343-350.

[19] C. Zhu, J. Liang, Z. Cao, J. Phys. Chem. C, 2013, 117, 13388-13395.

[20] C. Brückner, C. A. Barta, R. P. Briñas, J. A. K. Bauer, Inorg. Chem., 2003, 42, 1673-1680.

[21] I. Aviv, Z. Gross, Chem. Commun., 2007, 1987-1999.

[22] P. Li, Z. Cao, Dalton Trans., 2019, 48, 1344-1350.

[23] K. A. Prokop, D. P. Goldberg, J. Am. Chem. Soc., 2012, 134,
8014-8017.

[24] C. Zhu, J.-X. Liang, Z. Cao, J. Phys. Chem. C, 2018, 122, 20781-20786.

[25] J. P. T. Zaragoza, T. H. Yosca, M. A. Siegler, P. Moënne-Loccoz, M. T. Green, D. P. Goldberg, J. Am. Chem. Soc., 2017, 139, 13640-13643.

[26] X. He, Q. He, Y. Deng, M. Peng, H. Chen, Y. Zhang, S. Yao, M. Zhang, D. Xiao, D. Ma, B. Ge, H. Ji, Nat. Commun., 2019, 10, 3663.

[27] T. Stergiannakos, E. Tylianakis, E. Klontzas, P. N. Trikalitis, G. E. Froudakis, J. Phys. Chem. C, 2012, 116, 8359-8363.

[28] Y. Wang, W. Zhang, D. Deng, X. Bao, Chin. J. Catal., 2017, 38, 1443-1453.

[29] M.-J. Sun, X. Cao, Z. Cao, Nanoscale, 2018, 10, 10450-10458.

[30] L. Wu, X. Cao, W. Hu, Y. Ji, Z.-Z. Zhu, X.-F. Li, ACS Appl. Energy Mater., 2019, 2, 6634-6641.

[31] J.-X. Liang, J. Lin, J. Liu, X. Wang, T. Zhang, J. Li, Angew. Chem. Int. Ed., 2020, 59, 12868-12875.

[32] A. Wang, J. Li, T. Zhang, Nat. Rev. Chem., 2018, 2, 65-81.

[33] B. Qiao, A. Wang, X. Yang, L. F. Allard, Z. Jiang, Y. Cui, J. Liu, J. Li, T. Zhang, Nat. Chem., 2011, 3, 634-641.

[34] Y. Pan, Y. Chen, K. Wu, Z. Chen, S. Liu, X. Cao, W.-C. Cheong, T. Meng, J. Luo, L. Zheng, C. Liu, D. Wang, Q. Peng, J. Li, C. Chen, Nat. Commun., 2019, 10, 4290.

[35] K. Jiang, S. Back, A. J. Akey, C. Xia, Y. Hu, W. Liang, D. Schaak, E. Stavitski, J. K. Nørskov, S. Siahrostami, H. Wang, Nat. Commun., 2019, 10, 3997.

[36] M. Flytzani-Stephanopoulos, Chin. J. Catal., 2017, 38, 1432-1442.

[37] K. Liu, X. Zhao, G. Ren, T. Yang, Y. Ren, A. F. Lee, Y. Su, X. Pan, J. Zhang, Z. Chen, J. Yang, X. Liu, T. Zhou, W. Xi, J. Luo, C. Zeng, H. 
Matsumoto, W. Liu, Q. Jiang, K. Wilson, A. Wang, B. Qiao, W. Li, T. Zhang, Nat. Commun., 2020, 11, 1263.

[38] J. Liang, X. Yang, C. Xu, T. Zhang, J. Li, Chin. J. Catal., 2017, 38, 1566-1573.

[39] Y. Ren, Y. Tang, L. Zhang, X. Liu, L. Li, S. Miao, D. Sheng Su, A. Wang, J. Li, T. Zhang, Nat. Commun., 2019, 10, 4500.

[40] B. Qiao, J.-X. Liang, A. Wang, J. Liu, T. Zhang, Chin. J. Catal., 2016, 37, 1580-1586.

[41] Y. Tang, C. Asokan, M. Xu, G. W. Graham, X. Pan, P. Christopher, J. Li, P. Sautet, Nat. Commun., 2019, 10, 4488.

[42] F. Chen, X. Jiang, L. Zhang, R. Lang, B. Qiao, Chin. J. Catal., 2018, 39, 893-898.

[43] T. Yang, R. Fukuda, S. Hosokawa, T. Tanaka, S. Sakaki, M. Ehara, ChemCatChem, 2017, 9, 1222-1229.

[44] M. Zhou, M. Yang, X. Yang, X. Zhao, L. Sun, W. Deng, A. Wang, J. Li, T. Zhang, Chin. J. Catal., 2020, 41, 524-532.

[45] Y.-G. Wang, D. Mei, V.-A. Glezakou, J. Li, R. Rousseau, Nat. Commun., 2015, 6, 6511.

[46] Y. Tang, Y.-G. Wang, J.-X. Liang, J. Li, Chin. J. Catal., 2017, 38, 1558-1565.

[47] B. Qiao, J. Lin, A. Wang, Y. Chen, T. Zhang, J. Liu, Chin. J. Catal,, 2015, 36, 1505-1511.

[48] Q. Shang, N. Tang, H. Qi, S. Chen, G. Xu, C. Wu, X. Pan, X. Wang, Y. Cong, Chin. J. Catal., 2020, 41, 1812-1817.

[49] J. Liang, Q. Yu, X. Yang, T. Zhang, J. Li, Nano Res., 2018, 11, 1599-1611.

[50] R. Shediac, M. H. B. Gray, H. T. Uyeda, R. C. Johnson, J. T. Hupp, P. J. Angiolillo, M. J. Therien, J. Am. Chem. Soc., 2000, 122, 7017-7033.

[51] M. J. Frisch, G. W. Trucks, H. B. Schlegel, G. E. Scuseria, M. A. Robb, J. R. Cheeseman, G. Scalmani, V. Barone, B. Mennucci, G. A. Petersson, H. Nakatsuji, M. Caricato, X. Li, H. P. Hratchian, A. F. Izmaylov, J. Bloino, G. Zheng, J. L. Sonnenberg, M. Hada, M. Ehara, K. Toyota, R. Fukuda, J. Hasegawa, M. Ishida, T. Nakajima, Y. Honda, O. Kitao, H. Nakai, T. Vreven, J. A. Jr., Montgomery, J. E. Peralta, F. Ogliaro, M. Bearpark, J. J. Heyd, E. Brothers, K. N. Kudin, V. N. Staroverov, R. Kobayashi, J. Normand, K. Raghavachari, A. Rendell, J. C. Burant, S. S. Iyengar, J. Tomasi, M. Cossi, N. Rega, N. J. Millam, M. Klene, J. E. Knox, J. B. Cross, V. Bakken, C. Adamo, J. Jaramillo, R. Gomperts, R. E. Stratmann, O. Yazyev, A. J. Austin, R. Cammi, C. Pomelli, J. W.
Ochterski, R. L. Martin, K. Morokuma, V. G. Zakrzewski, G. A. Voth, P. Salvador, J. J. Dannenberg, S. Dapprich, A. D. Daniels, Ö. Farkas, J. B. Foresman, J. V. Ortiz, J. Cioslowski, D. J. Fox, Gaussian 09, Revision B.01, Gaussian, Inc., Wallingford CT, 2009.

[52] C. Lee, W. Yang, R. G. Parr, Phys. Rev. B, 1988, 37, 785-789.

[53] A. D. Becke, J. Chem. Phys., 1993, 98, 5648-5652.

[54] G. Kresse, J. Hafner, Phys. Rev. B, 1993, 47, 558-561.

[55] G. Kresse, D. Joubert, Phys. Rev. B, 1999, 59, 1758-1775.

[56] S. L. Dudarev, G. A. Botton, S. Y. Savrasov, C. J. Humphreys, A. P. Sutton, Phys. Rev. B, 1998, 57, 1505-1509.

[57] A. Wadehra, J. W. Nicklas, J. W. Wilkins, Appl. Phys. Lett., 2010, 97, 092119.

[58] P. Deák, B. Aradi, T. Frauenheim, E. Janzén, A. Gali, Phys. Rev. B, 2010, 81, 153203.

[59] J. X. Liang, S. B. Tang, Z. X. Cao, J. Phys. Chem. C, 2011, 115, 18802-18809.

[60] S. Grimme, J. Antony, S. Ehrlich, H. Krieg, J. Chem. Phys., 2010, 132, 154104.

[61] A. Kumar, I. Goldberg, M. Botoshansky, Y. Buchman, Z. Gross, J. Am. Chem. Soc., 2010, 132, 15233-15245.

[62] J.-X. Liang, C.-J. Zhang, Acta Chim. Sin., 2010, 68, 7-12.

[63] R. O. Jones, J. Chem. Phys., 1999, 110, 5189-5200.

[64] C. Zhang, W. Sun, Z. Cao, J. Am. Chem. Soc., 2008, 130, 5638-5639.

[65] N. Tsunoji, H. Nishida, Y. Ide, K. Komaguchi, S. Hayakawa, Y. Yagenji, M. Sadakane, T. Sano, ACS Catal., 2019, 9, 5742-5751.

[66] J. Li, Z. Zhang, L. Wu, W. Zhang, P. Chen, Z. Lin, G. Liu, Nature, 2019 , 574, 516-521.

[67] V. Postils, M. Rodríguez, G. Sabenya, A. Conde, M. M. Díaz-Requejo, P. J. Pérez, M. Costas, M. Solà, J. M. Luis, ACS Catal., 2018, 8, 4313-4322.

[68] S. Shaik, D. Kumar, S. P. de Visser, A. Altun, W. Thiel, Chem. Rev., 2005, 105, 2279-2328.

[69] P. Schwach, X. Pan, X. Bao, Chem. Rev., 2017, 117, 8497-8520.

[70] N. J. Gunsalus, A. Koppaka, S. H. Park, S. M. Bischof, B. G. Hashiguchi, R. A. Periana, Chem. Rev., 2017, 117, 8521-8573.

[71] J. Lin, X. Wang, Sci. China Mater., 2018, 61, 758-760.

[72] Z. Wang, D. Danovich, R. Ramanan, S. Shaik, J. Am. Chem. Soc., 2018, 140, 13350-13359.

[73] J. Joy, T. Stuyver, S. Shaik, J. Am. Chem. Soc., 2020, 142, 3836-3850.

\title{
基于氮杂Mn咔咯二维纳米材料的单原子Mn中心催化氧化烷烃制醇
}

\author{
朱 纯 ${ }^{\mathrm{a}}$, 梁锦霞, 孟 洋 ${ }^{\mathrm{a}}$, 林 坚, ${ }^{\mathrm{c}}$, 曹泽星, ${ }^{\mathrm{d}, \#}$ \\ 贵州大学化学与化工学院, 贵州贵阳 550025

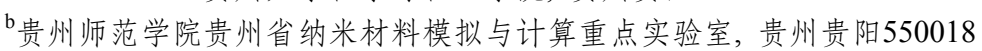 \\ c 中国科学院大连化学物理研究所, 中国科学院航天催化材料重点实验室, 辽宁大连 116023 \\ d厦门大学化学化工学院, 福建省理论与计算化学重点实验室, 福建厦门360015
}

摘要: 咔咯是由四个吡咯共轭相连而形成的具有芳香性的新型卟啉类大环化合物, 但咔咯分子中存在一个直接连结两个 吡咯环的 $\mathrm{C}-\mathrm{C}$ 键, 与卟啉相比, 仅仅是少了一个“meso”位置的 C原子. 因此, 在结构上, 咔咯含有三个“吡咯型”氮原子和一个 “吡啶型”氮原子, 当咔咯失去三个内氢原子后变成了三价阴离子, 易与金属形成高价态的稳定配合物. 氮杂咔咯是一种咔 咯的meso位上的 $\mathrm{C}$ 被取代为 $\mathrm{N}$ 的咔咯衍生物. 与正常的咔咯相比, 它更易于与过渡金属形成稳定配合物. 正是由于这些独 特的结构特点, 使其在金属催化、染料敏化太阳能电池、光敏剂、金属传感器、甚至在医学上都有很好的应用前景.

金属有机大环均相催化剂的非均相化, 是改进反应产物分离和实现催化剂循环使用的最简单有效方法之一. 环境友 好的 $\mathrm{Mn}$ 氮杂咔咯催化剂, 在温和条件下可以利用氧气直接将有机底物氧化. 本文选用 $\mathrm{Mn}$ 氮杂咔咯催化剂作为基本构建单 元, 通过理论计算, 构建了一种新型的具有高催化活性的含Mn氮杂咔咯环结构单元的二维纳米催化材料. 我们分别使用高 斯软件(Gaussian 09)和维也纳从头算模拟软件包(VASP)对孤立分子和周期性体系进行结构优化以及性质的计算. 在这种 
二维材料中, 每一个 $\mathrm{Mn}$ 原子作为相对独立的金属单原子中心 $(\mathrm{SAC})$, 保留了单环中 $\mathrm{Mn}$ 金属中心的高催化活性. 在温和的光 照条件下, $\mathrm{Mn}$ 金属中心可以直接活化氧气生成类自由基[Mn]-O-O中心, 随后[Mn]-O-O中心可以有效地通过夺取有机底物 中的 $\mathrm{H}$ 和紧接着新生自由基的偶合反应, 选择性氧化 $\mathrm{C}-\mathrm{H}$ 键为 $\mathrm{C}-\mathrm{OH}$ 键. 另外, 通过沿[Mn]-O-O应轴施加不同强度的外 电场, 可对此二维纳米材料的催化反应活性进行精细调控. 本文为实验上制备基于 $\mathrm{Mn}$ 氮杂咔咯的非均相催化剂以及单原 子 $\mathrm{Mn}$ 基催化剂提供了理论依据.

关键词: 单原子催化剂; 非均相化; 二维纳米材料; 第一性原理计算; $\mathrm{C}-\mathrm{H}$ 键的活化

收稿日期: 2020-07-06. 接受日期: 2020-08-25. 上网日期: 2020-11-22.

*通讯联系人. 电话: (0411)84379673; 传真: (0411)84685940; 电子信箱: jianlin@dicp.ac.cn

通讯联系人. 电话: (0592)2186081; 传真: (0592)2183047; 电子信箱: zxcao@xmu.edu.cn

基金来源：国家自然科学基金(21663008, 21763006, 2193309, 21963005, 21878283, 22022814); 贵州省自然科学基金([2017]1029);

中国科学院青年创新促进会(2017223).

本文的电子版全文由Elsevier出版社在ScienceDirect上出版(http://www.sciencedirect.com/science/journal/18722067). 